\title{
Impact of planting density on wheat crop grown under different tree species in tarai agroforestry system of Central himalaya, India
}

\author{
Kavita Satyawali*, Sumit Chaturvedi, Neema Bisht and V.C. Dhyani \\ College of Agriculture, Govind Ballabh Pant University of Agriculture and Technology, Pantnagar, U. S. Nagar- \\ 263145 (Uttarakhand), INDIA \\ *Corresponding author. E-mail: kavita.satyawali19@gmail.com \\ Received: May 20, 2017; Revised received: July 19, 2017; Accepted: January 1, 2018
}

\begin{abstract}
A field trial based Agroforestry system was established at Pantnagar during Rabi season 2012-13 for predicting the effect of spacing on growth and yield of wheat (Triticum aestivum L.) under Eucalyptus camaldulensis and Melia azedarach. The experiment was carried out in split-plot design consisting of two tree species in main plot, viz, Eucalyptus camaldulensis and Melia azedarch and four spacing treatments in sub-plot viz, $3.0 \mathrm{~m} \times 1.0 \mathrm{~m}$, $3.0 \mathrm{~m} \times 1.5 \mathrm{~m}, 3.0 \mathrm{~m} \times 2.0 \mathrm{~m}$ and $3.0 \mathrm{~m} \times 2.5 \mathrm{~m}$ with three replications. The wheat crop variety"UP-2338" was sown on December 06, 2012 and harvested on April 27, 2013. Among the tree species, the maximum (15.1 q /ha) and significantly higher grain yield with $21.8 \%$ increment was recorded under Melia as compare to Eucalyptus. Whereas, among the different spacings, the wheat growth in terms of dry biomass at 120 DAS $\left(495.4 / \mathrm{m}^{2}\right)$, yield attributes and yield in terms of grain (16.0 q/ha), straw (29.4 q/ha) and biological yield (45.4 q/ha) under Melia was significantly higher at $3 \times 2.5 \mathrm{~m}$ spacing as compared to other planting density. The correlation coefficient $(r)$ studies exhibited that wheat growth and yield attributing characteristics shows significantly $(p<0.05)$ high degree $(r=0.75$ to 1$)$ positive correlation with each other. The investigation was done to find out the proper planting density for intercropping of wheat with tree species without comprising the wheat growth and enhancing its sustainability.
\end{abstract}

Keywords: Eucalyptus camaldulensis, Planting density, Tree species, Wheat, Yield

\section{INTRODUCTION}

Agroforestry is an important component of the 'evergreen revolution' movement in the country (Puri and Nair, 2004).According to Gibson (1978), agroforestry under high density short rotation plantation has maximum advantages including higher yield per unit area of land and increased labour productivity than conventional forestry. Agroforestry systems not only arrest land degradation but also improve site productivity through interactions among trees, soil, crops, and livestock (Kumar, 2006). This is the most important way to practice agriculture without deteriorating agrodiseases and environmental degradation is highly appreciable (Garrity, 2004).

In North Indian states, wheat (Triticum aestivum L.) is the most important and staple food crop when grown under agroforestry system, which holds about 88.31 million tones of production in 2011-12 (Sarvade et al. 2014). In India, it is most widely grown cereal crop during Rabi season (November-April) which is intercropped with Eucalyptus, Poplar and other short rotation tree species of fast growing nature in Uttarakhand, U.P, Haryana, Punjab, Bihar states in north and parts of central and eastern states of Madhya Pradesh, Chhattisgarh and West Bengal.
The major advantage of agroforestry is that both wood and agricultural products come from the same land base, making it an efficient production system especially in areas where farmers have small holdings. In agroforestry, the micro-climate is modified by different tree species. Under such situations, role of agroforestry in the light of combating hunger, the response of wheat crop under storey might be different from the sole system of cropping. In Indo-Gangetic plains, the technology of wheat production is very well established but may require some refinement in mixed landuse systems technology, like agroforestry, particularly in terms of nutrient management aspect, where wheat crop is grown in association with the trees.

For increasing the food and raw material for industry requirement, intercropping with tree species under high density short rotation is the most appropriate method of natural resources through sustainable utilization of resources (Sarvade et al., 2014). Melia azedarach is now becoming increasingly common under high density, short-rotation mixed plantations for site amelioration and may have the potential to increase crop yields, maintain soil fertility, also provides fuel wood and fodder.

Hence, the experiment was aimed to ascertain the influence of different tree species and their spacing in 
development and yield of wheat crop.

\section{MATERIALS AND METHODS}

The field experiment was conducted at Agroforestry research center, G. B. Pant University of Agriculture and Technology, Pantnagar, Uttarakhand $\left(29^{\circ} \mathrm{N}\right.$ Latitude, $79^{\circ} 30^{\prime} \mathrm{E}$ longitude and at an altitude of 243.84 msl) during 2012-2013. The plot comprised silty-clayloam soil with 1.53 and $1.57 \%$ of organic carbon and 253.65 and $365 \mathrm{~kg} / \mathrm{ha}$ of available nitrogen, 32.32 and $35.84 \mathrm{~kg} / \mathrm{ha}$ of available phosphorus and 176.55 and $220.4 \mathrm{~kg} /$ haof exchangeable potassium in Eucalyptus and Melia, respectively.

\begin{tabular}{|c|c|}
\hline Particulars & Method employed \\
\hline Soil texture & Silty clay loam \\
\hline Sand $\%$ & $10 \%$ \\
\hline Silt $\%$ & $50 \%$ \\
\hline Clay \% & $32 \%$ \\
\hline & $\begin{array}{l}\text { Derived by Bouyoucas hydrom- } \\
\text { eter method (Bouyoucas,1962) }\end{array}$ \\
\hline $\begin{array}{l}\text { Organic } \\
(\%)\end{array}$ & $\begin{array}{l}\text { Modified Walkley and Black } \\
\text { method (Jackson,1973) }\end{array}$ \\
\hline $\begin{array}{l}\text { Available Nitrogen } \\
\left(\mathrm{kg} \mathrm{ha}^{-1}\right)\end{array}$ & $\begin{array}{l}\text { Alkaline KMnO4 method } \\
\text { (Subbiah and Asija, 1956) }\end{array}$ \\
\hline $\begin{array}{l}\text { Available phos- } \\
\text { phorus }\left(\mathrm{kg} \mathrm{ha}^{-1}\right)\end{array}$ & Olsen's method (Jackson,1973) \\
\hline $\begin{array}{l}\text { Available potassi- } \\
\operatorname{um}\left(\mathrm{kg} \mathrm{ha}^{-1}\right)\end{array}$ & $\begin{array}{l}\text { Flame emission spectrophotom- } \\
\text { eter (Jackson,1973) }\end{array}$ \\
\hline
\end{tabular}

\section{Important physio-chemical properties of} experimental soil

The site is characterized by a humid sub-tropical, cold and hot dry summers with $1350 \mathrm{~mm}$ mean annual rainfall, of which 80 to $90 \%$ is received between June and September. The remaining 10 to $20 \%$ rainfall is received during wheat-growing season (November to April of year 2012-13). The weather data was collected from the agrometeorological observatory located at the Norman E. Borlaug Crop Research Centre, G. B. Pant University of Agriculture and Technology, Pantnagar. Intercropping of wheat crop was done under short rotation fast growing tree species. Two tree species of T1: Eucalyptus, K23 (Eucalyptus camaldulensis) and T2: Melia, Local (Melia azedarach) were planted in 2007 with four spacing treatments of S1: $3 \mathrm{~m} \times 1.0 \mathrm{~m}, \mathrm{~S} 2$ : $3 \mathrm{~m} \times 1.5 \mathrm{~m}, \mathrm{~S} 3: 3 \mathrm{~m} \times 2 \mathrm{~m}$ and S4: $3 \mathrm{~m} \times 2.5 \mathrm{~m}$. The wheat (UP-2338)was sown with a uniform row-to-row distance of $17.5 \mathrm{~cm}$ using seed rate $100 \mathrm{~kg} / \mathrm{ha}$. The crop was fertilized with $120 \mathrm{~kg} \mathrm{~N}, 60 \mathrm{~kg} \mathrm{P}_{2} \mathrm{O}_{5}$ and 40 $\mathrm{kg} \mathrm{K}_{2} \mathrm{O}$ per hectare through urea, single super phosphate and murate of potash, respectively. Half dose of nitrogen $(60 \mathrm{~kg} / \mathrm{ha})$ and full dose of phosphorus (60 $\mathrm{kg} / \mathrm{ha})$ and potash $(40 \mathrm{~kg} / \mathrm{ha})$ were applied as basal dressing and mixed thoroughly with the help of spade manually before crop sowing. Remaining dose of nitrogen was top dressed a day before first irrigation at
Crown Root Initiation CRI stage. Wheat crop was irrigated thrice (at crown root initiation, late jointing and milk stages of the crop growth). However, no separate irrigation was provided for tree component. For the control of weeds, a broad spectrum herbicide (Sulfosulfuron@25g a.i. /ha) was sprayed at 35th days after sowing (DAS). The experiment was designed as split-split-plot with two species in main plots, spacing in sub-plots and treatments were replicated thrice.

The dry matter accumulation was recorded at maturity stage (120 DAS). The different yield attributing characters like spike length $(\mathrm{cm})$, fertile spikelet/ spike, sterile spikelet/spike, grain number/spike and 1000grain weight were evaluated at time of physiological maturity. The net plots were harvested to obtain grain/ seed, straw and biological yield. Harvest index was calculated as the ratio of grain to total biological yield. Data obtained during the course of this investigation, was analyzed by using standard statistical procedure for split plot design with the help of computer for analysis of variance (ANOVA) technique (Snedecor and Cochran, 1967). Standard error of mean (SEm \pm ) were computed in each case. The differences among treatments were compared by applying " $F$ " test of significance at 5\% probability. Correlation studies (Panse and Sukhatme, 1978) were also performed to study the inter-relationship between various parameters.

\section{RESULTS AND DISCUSSION}

Wheat growth: Dry matter accumulation in wheat crop $\left(\mathrm{g} / \mathrm{m}^{2}\right)$ at 120 DAS was significantly influenced by tree species and their spacing (Table 1 ). Dry matter accumulation was significantly higher in Melia (526.3 $\left.\mathrm{g} / \mathrm{m}^{2}\right)$ as compared to Eucalyptus $\left(428.5 \mathrm{~g} / \mathrm{m}^{2}\right)$ which shows about $22.8 \%$ increase in biomass accumulation. Whereas, among the different spacing, significantly higher dry matter of wheat was recorded at maximum spacing of $3.0 \mathrm{~m} \times 2.5 \mathrm{~m}$. Reduction under Eucalyptus may be attributed to its allelopathic effect on understory crops and more canopy density resulting in greater shade. Similar findings were recorded by Fikreyesus et al. (2011) in the case of tomato; Ahmed et al. (2008); Kaushik and Singh (2001) for agricultural Rabi crops. The wheat produced highest total plant dry matter with widest spacing $(3.0 \mathrm{~m} \times 2.5 \mathrm{~m})$ under both the tree species and consistent reduction was observed with each decrease in tree spacing. Sarvade et al. (2014) reported $10.3 \%$ reduction of dry matter accumulation $\left(\mathrm{g} / \mathrm{m}^{2}\right)$ with decrease in plant spacing from $3.0 \mathrm{~m} \times 2.5 \mathrm{mto}$ $3.0 \mathrm{~m} \times 1.0 \mathrm{~m}$. The reduction in dry matter accumulation $\left(\mathrm{g} / \mathrm{m}^{2}\right)$ with increased tree density has primarily been attributed due to increased shading effects and competition for nutrients, space and water. Being an evergreen tree species, Eucalyptus reduces light availability and decreased crop yield. Corroborative results were reported by Kaushik and Singh (2001), Kumar 
Kavita Satyawali et al. / J. Appl. \& Nat. Sci. 10 (1): 30 - 36 (2018)
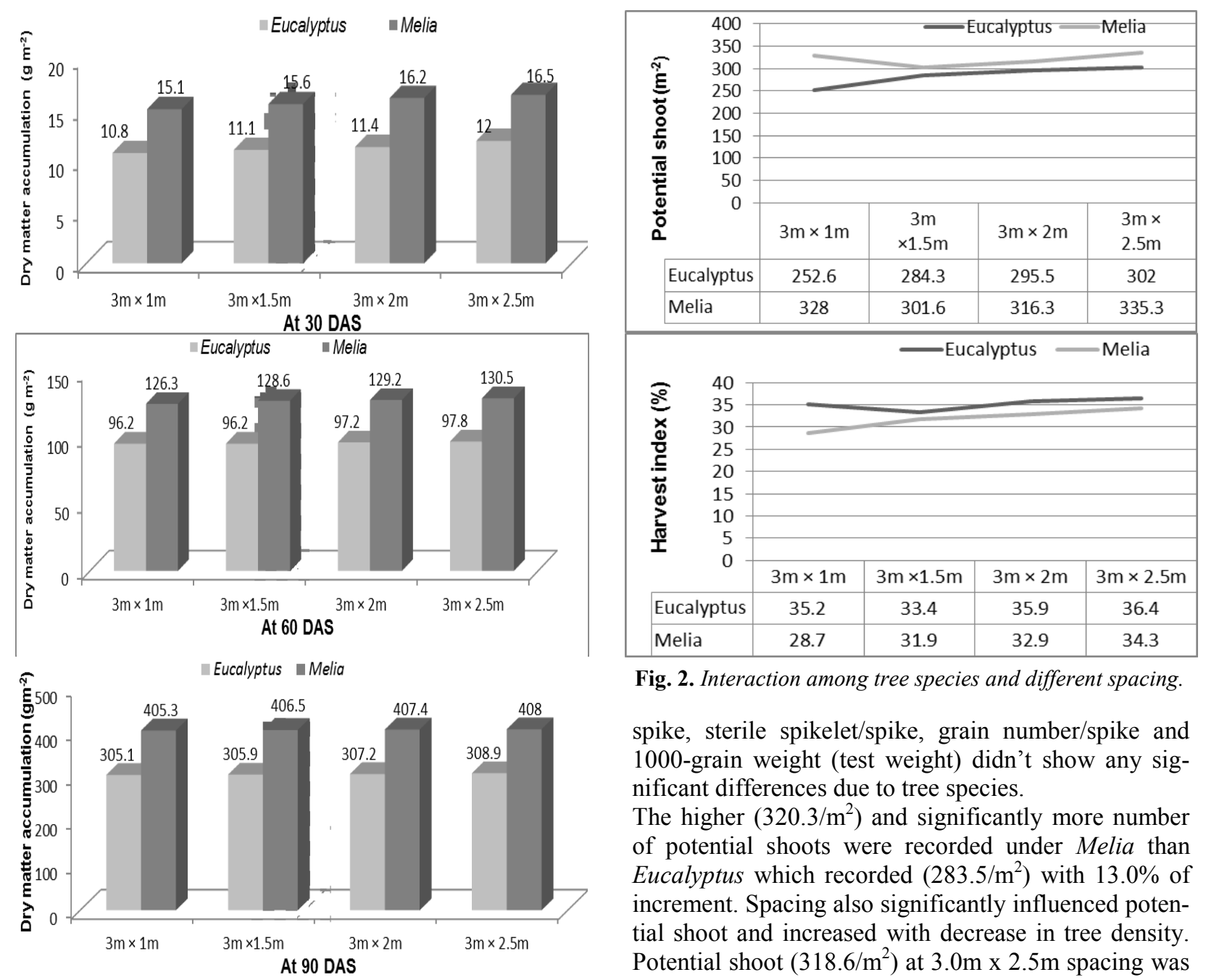

Fig. 2. Interaction among tree species and different spacing

spike, sterile spikelet/spike, grain number/spike and 1000-grain weight (test weight) didn't show any significant differences due to tree species.

The higher $\left(320.3 / \mathrm{m}^{2}\right)$ and significantly more number of potential shoots were recorded under Melia than Eucalyptus which recorded $\left(283.5 / \mathrm{m}^{2}\right)$ with $13.0 \%$ of increment. Spacing also significantly influenced potential shoot and increased with decrease in tree density. Potential shoot $\left(318.6 / \mathrm{m}^{2}\right)$ at $3.0 \mathrm{~m} \times 2.5 \mathrm{~m}$ spacing was significantly higher than $3.0 \mathrm{~m} \times 1.0 \mathrm{~m}$ and $3.0 \mathrm{~m} \times 1.5 \mathrm{~m}$ spacing but was at par with $3.0 \mathrm{~m} \times 2.0 \mathrm{~m}$ spacing.

Spike length was significantly influenced by spacing and increase with decreased in tree density. Melia recorded $13.1 \%$ increment over Eucalyptus. It was found to be higher $(9.65 \mathrm{~cm})$ at $3.0 \mathrm{~m} \times 2.5 \mathrm{~m}$ spacing and was at par with its respective lower dose at $3.0 \mathrm{~m} \times 2.0 \mathrm{~m}$ acters viz, average spike length $(\mathrm{cm})$, fertile spikelet/

Table1. Effect of different tree species and spacing on wheat growth and yield attributes.

\begin{tabular}{|c|c|c|c|c|c|c|c|c|}
\hline Treatments & $\begin{array}{l}\text { Germina- } \\
\text { tion count } \\
\left(\operatorname{per} \mathbf{m}^{2}\right)\end{array}$ & $\begin{array}{l}\text { Dry matter accumu- } \\
\text { lation } \\
\left(\text { per } \mathrm{m}^{2}\right) \text { at } 120 \mathrm{DAS}\end{array}$ & $\begin{array}{l}\text { Potential } \\
\text { shoot (per } \\
\text { m }^{2} \text { ) }\end{array}$ & $\begin{array}{l}\text { Spike } \\
\text { length } \\
\text { (cm) }\end{array}$ & $\begin{array}{l}\text { Fertile } \\
\text { spikelet/ } \\
\text { spike }\end{array}$ & $\begin{array}{l}\text { Sterile } \\
\text { spikelet/ } \\
\text { spike }\end{array}$ & $\begin{array}{l}\text { Grain } \\
\text { /spike }\end{array}$ & $\begin{array}{l}1000 \\
\text { grain } \\
\text { weight(g) }\end{array}$ \\
\hline Sole crop & 274.3 & 1051.6 & 400.3 & 10.6 & 17.3 & 3.0 & 45.6 & 43.4 \\
\hline \multicolumn{9}{|l|}{ A. Tree species } \\
\hline Eucalyptus & 205.0 & 428.5 & 283.5 & 8.41 & 15.11 & 1.60 & 30.2 & 25.69 \\
\hline Melia & 217.6 & 526.3 & 320.3 & 9.51 & 16.21 & 2.25 & 35.7 & 30.36 \\
\hline $\mathrm{SEd} \pm$ & 2.54 & 2.70 & 3.50 & 0.36 & 0.37 & 0.55 & 2.67 & 1.65 \\
\hline $\mathrm{CD}(\mathrm{P}=0.05)$ & 10.63 & 11.32 & 14.66 & NS & NS & NS & NS & NS \\
\hline \multicolumn{9}{|l|}{ B. Tree spacing } \\
\hline $3 \mathrm{~m} \times 1 \mathrm{~m}$ & 200.5 & 464.3 & 290.3 & 5.48 & 15.5 & 1.83 & 29.16 & 26.65 \\
\hline $3 \mathrm{~m} \times 1.5 \mathrm{~m}$ & 208.3 & 473.0 & 293.0 & 8.30 & 15.0 & 1.50 & 32.0 & 26.25 \\
\hline $3 \mathrm{~m} \times 2 \mathrm{~m}$ & 214.1 & 477.0 & 305.8 & 9.13 & 15.8 & 2.16 & 34.33 & 28.59 \\
\hline $3 \mathrm{~m} \times 2.5 \mathrm{~m}$ & 222.3 & 495.4 & 318.6 & 9.65 & 16.3 & 2.21 & 36.50 & 30.63 \\
\hline $\mathrm{SEd} \pm$ & 5.47 & 3.96 & 7.38 & 0.29 & 0.29 & 0.29 & 1.56 & 0.70 \\
\hline $\mathrm{CD}(\mathrm{P}=0.05)$ & 11.93 & 8.63 & 16.08 & 0.64 & 0.64 & NS & 3.41 & 1.54 \\
\hline Interaction $(\mathbf{A} \times \mathbf{B})$ & NS & NS & $\mathrm{S}$ & NS & NS & NS & $\mathrm{NS}$ & NS \\
\hline
\end{tabular}


Kavita Satyawali et al. / J. Appl. \& Nat. Sci. 10 (1): 30 - 36 (2018)

Table 2.Yield of wheat crop under tree species and their spacing under high density plantation.

\begin{tabular}{lcccc}
\hline \multirow{2}{*}{ Treatments } & \multicolumn{3}{c}{ Yield attributes $(\mathbf{q} / \mathbf{h a})$} \\
\cline { 2 - 5 } & Grain yield & Straw yield & Biological yield & Harvest index (\%) \\
\hline Sole crop & $\mathbf{2 7 . 9}$ & $\mathbf{5 1 . 8}$ & $\mathbf{7 9 . 7}$ & $\mathbf{3 5 . 5}$ \\
\hline A.Tree species & & & & 35.3 \\
\hline Eucalyptus & 12.4 & 22.7 & 35.1 & 32.0 \\
Melia & 15.1 & 31.9 & 47.1 & 0.99 \\
SEd \pm & 0.33 & 0.39 & 0.07 & NS \\
CD $(\mathrm{P}=0.05)$ & 1.42 & 1.63 & 0.29 & 32.0 \\
\hline B.Tree spacing & & & & 32.7 \\
\hline m $\times 1 \mathrm{~m}$ & 11.5 & 25.1 & 36.6 & 34.4 \\
$3 \mathrm{~m} \times 1.5 \mathrm{~m}$ & 13.0 & 26.9 & 39.9 & 35.4 \\
$3 \mathrm{~m} \times 2 \mathrm{~m}$ & 14.5 & 27.9 & 42.5 & 0.79 \\
$3 \mathrm{~m} \times 2.5 \mathrm{~m}$ & 16.0 & 29.4 & 45.4 & 1.72 \\
SEd \pm & 0.41 & 0.33 & 0.50 & $\mathrm{~S}$ \\
$\mathrm{CD}(\mathrm{P}=0.05)$ & 0.90 & 0.72 & 1.10 & $\mathrm{NS}$ \\
Interaction $(\mathbf{A} \times \mathbf{B})$ & $\mathrm{NS}$ & $\mathrm{NS}$ & & \\
\hline
\end{tabular}

spacing and significantly superior to rest of the spacings. Similar results were recorded with fertile spikelets/spike with $7.3 \%$ as comparison to Eucalyptus. Maximum fertile spikelets/spike (16.3) was obtained under $3.0 \mathrm{~m} \times 2.5 \mathrm{~m}$ spacing and decreased with decrease in density of tree species except with $3.0 \mathrm{~m} \mathrm{x}$ $1.5 \mathrm{~m}$ spacing.

The highest (36.50) grains/spike have been recorded under $3.0 \mathrm{~m} \times 2.5 \mathrm{~m}$ spacing. The number of grains/ spike at $3.0 \mathrm{~m} \times 2.5 \mathrm{~m}$ spacing was significantly higher than $3.0 \mathrm{~m} \times 1.0 \mathrm{~m}$ and $3.0 \mathrm{~m} \times 1.5 \mathrm{~m}$ spacing and was at par under $3.0 \mathrm{~m} \times 1.5 \mathrm{~m}$ spacing. Test weight at $3.0 \mathrm{~m} \times$ $2.5 \mathrm{~m}$ spacing $(30.63 \mathrm{~g})$ was significantly higher than all other spacing. However, the difference between the thousand grains weight with $3.0 \mathrm{~m} \times 1.0 \mathrm{~m}$ and $3.0 \mathrm{~m} \times$ $1.5 \mathrm{~m}$ spacing was found to be non-significant. Melia shows $18.2 \%$ of increment in grains/spike than Eucalyptus. The yield attributes are mainly depends on the crop growth and significantly affected by tree species and as they affect wheat growth. Similar findings have been reported by various scientists (Jiang et al., 1994; Khan and Ehrenreich, 1994; Lakshmamma and Subba Rao, 1996; Tripathi et al., 2006). Puri et al. (2001) also found the number of effective tillers and seeds per spike in wheat to be influenced significantly in agrisilvicultural system with significant varietal differences. It is visualized that higher potential shoots and more number of grains/spikehave basically been responsible for higher grain yield in wheat. Number of grains/spike has been shown to be reduced by shading during ear growth (Fischer and Stockman, 1980; Stockman et al.,1983; Fischer, 1985).Puri et al. (2001) also found the number of effective tillers and seeds per spike in wheat to be influenced significantly in agrisilvicultural system with significant varietal differences. The significant reduction in test weight and pods/plant of lentil and mungbean under varying spacing of Dalbergia sissoo compared to open have also been reported by Nandal and Singh (2001). The present study shows that Eucalyptus being an evergreen species affects the yield and yield attributing characters of wheat due to its shading effect. Similarly, Nazir et al. (1993) also observed that 1000-grain weight of wheat decreased significantly under Dalbergia sissoo with increased duration of shading. Similar findings have been reported by Tripathi et al., 2006.

Yield: Crop yield was influenced differently by different tree species and spacing. The maximum total biological, grain, straw wheat yields were obtained under control (sole crop) which was substantially high than Melia and Eucalyptus (Table 2). All the yield attributing characters viz., grain, straw and biological yield were achieved maximum (15.1, 31.9 and 47.1 q/ha), respectively, when intercropped with Melia and was significantly superior to wheat intercropped with Eucalyptus with increase percent of $21.8,40.5$ and $34.2 \%$, respectively. Among the different spacing, $3 \mathrm{~m} \times$ $2.5 \mathrm{mspacing}$ was proved to be more effective and significantly superior in obtaining maximum yield than its respective other spacing. However, interaction among the different tree species and spacing was found to be non significant. The yields (biological, grain and straw) were observed and the per cent reduction was recorded higher under Eucalyptus (55.55, 56.20 and $55.97 \%$, respectively) than Melia $(45.87,38.45$ and $40.91 \%$, respectively) in comparison to sole crop condition. Number of studies has shown reduced grain, straw and/or biological yields under trees (Kaushik and Singh, 2001; Puri et al., 2001; Kaushik et al., 2001 and Verma et al., 2002). Mu et al. (2010) reported that the wheat grain yield losses were proportionately less than the reduction in solar radiation under shading by trees in agroforestry and also corroborative findings have been reported by various scientists (Sidhu and Hans, 1988; Chauhan et al., 1995; Patil et al., 2002 and Kidanu et al., 2005)

Harvest index was recorded highest $(35.4 \%)$ with wider spacing at $3 \mathrm{~m} \times 2.5 \mathrm{~m}$ which was at par with its respective narrow spacing at $3 \mathrm{~m} \times 2.0 \mathrm{~m}$ but was at par with other two spacing $(3 \mathrm{~m} \times 1.0 \mathrm{~m}$ and $3 \mathrm{~m} \times 1.5 \mathrm{~m})$. Interaction among the tree species and spacing was significant. 
Table 3. Gross income and economic gain ( $/$ ha) over sole crop from agri-silvicultural system with different tree species and their spacings.

\begin{tabular}{|c|c|c|c|c|c|}
\hline \multirow{2}{*}{ Treatment } & \multirow{2}{*}{$\begin{array}{l}\text { Income from wheat } \\
\text { crop(/ha) }\end{array}$} & \multicolumn{2}{|c|}{ Income from Trees } & \multicolumn{2}{|c|}{ Total income from system } \\
\hline & & $\begin{array}{l}\text { Timber quantity } \\
\text { (Tonnes/ha) }\end{array}$ & $\begin{array}{l}\text { Income } \\
(\mathrm{ha} / \mathrm{ha})\end{array}$ & $\begin{array}{l}\text { (Timber+ wheat) (// } \\
\text { ha) }\end{array}$ & $\begin{array}{l}\text { Gain over sole crop } \\
(\mathrm{ha})\end{array}$ \\
\hline Sole crop & 44,198 & & & 44,198 & \\
\hline \multicolumn{6}{|l|}{ Tree species } \\
\hline Eucalyptus & 19,240 & 10.36 & 43,056 & 62,296 & 18,098 \\
\hline Melia & 23,904 & 6.19 & 24,763 & 48,667 & 4,469 \\
\hline \multicolumn{6}{|l|}{ Tree spacing } \\
\hline $3.0 \mathrm{~m} \times 1.0 \mathrm{~m}$ & 21,062 & 9.08 & 40,860 & 61,922 & 17,724 \\
\hline $3.0 \mathrm{~m} \times 1.5 \mathrm{~m}$ & 21,697 & 8.05 & 36,234 & 57,931 & 13,733 \\
\hline $3.0 \mathrm{~m} \times 2.0 \mathrm{~m}$ & 22,805 & 7.56 & 34,034 & 56,839 & 12,641 \\
\hline $3.0 \mathrm{~m} \times 2.5 \mathrm{~m}$ & 23,926 & 5.88 & 26,460 & 50,386 & 6,188 \\
\hline
\end{tabular}

Note: Total value was calculated according to current market price; '1120/qt for wheat, '250/qt for straw, `600/qt for Eucalyptus and Melia wood and '400/qt. For spacings- the average of timber prices of all the species was taken to calculate income.

Table 4. Correlation growth, yields attributes and yields of wheat under agroforestry system.

\begin{tabular}{|c|c|c|c|c|c|c|c|c|c|c|}
\hline Characters & 2 & 3 & 4 & 5 & 6 & 7 & 8 & 9 & 10 & 11 \\
\hline 1 & $.975^{* *}$ & $.990^{* *}$ & .707 & $.896^{* *}$ & $.903^{* *}$ & $.975^{* *}$ & $.991^{* *}$ & $1.000^{* *}$ & $.983^{* *}$ & $.993^{* *}$ \\
\hline 2 & & $.971^{* *}$ & .556 & $.840^{*}$ & $.858^{*}$ & $.913^{* *}$ & $.976^{* *}$ & $.978^{* * *}$ & $.985^{* *}$ & $.986^{* *}$ \\
\hline 3 & & & .676 & $.936^{* *}$ & $.940^{* *}$ & $.978^{* *}$ & $.998^{* *}$ & $.990^{* *}$ & $.993^{* *}$ & $.996^{* *}$ \\
\hline 4 & & & & .657 & .652 & $.804^{*}$ & .654 & .697 & .636 & .662 \\
\hline 5 & & & & & $.988^{* *}$ & $.932^{* *}$ & $.934^{* *}$ & $.894^{* *}$ & $.896^{* *}$ & $.899^{* *}$ \\
\hline 6 & & & & & & $.932^{* *}$ & $.939^{* *}$ & $.904^{* *}$ & $.907^{* *}$ & $.910^{* *}$ \\
\hline 7 & & & & & & & $.969^{* *}$ & $.972^{* *}$ & $.959^{* *}$ & $.967^{* *}$ \\
\hline 8 & & & & & & & & $.992^{* *}$ & $.990^{* *}$ & $.994^{* *}$ \\
\hline 9 & & & & & & & & & $.984^{* *}$ & $.994^{* *}$ \\
\hline 10 & & & & & & & & & & $.998^{* *}$ \\
\hline
\end{tabular}

** Significant at $1 \%$ level of probability; * Significant at $5 \%$ level of probability, Germination count; 2- dry matter accumulation at 120 DAS; 3- Potential shoot; 4- Spike length; 5- Fertile spike per spikelet; 6- Sterile spike per spikelet; 7- grains per spike; 8- 100 grain weight; 9- grain yield; 10- straw yield; 11- biological yield.

Economics of the system: Economic benefits from different tree species and their spacings in agrisilvicultural system with wheat as intercrop during this particular crop season are given in Table 4.7. For the calculation of timber quantity, the specific gravity (Pande, 2011), 0.60 and 0.66 has been taken for Eucalyptus and Melia species, respectively, whereas, for spacing, the average specific gravity of both timber species was taken.

Gross income for the system ( / / ha) was worked out to be ‘62296 and 48667/-for Eucalyptus and Melia, respectively, and $61922,57931,56839$ and 50386/- for tree spacing sviz. $3.0 \mathrm{~m} \times 1.0 \mathrm{~m}, 3.0 \mathrm{~m} \times 1.5 \mathrm{~m}, 3.0 \mathrm{~m} \times 2.0 \mathrm{~m}$ and $3.0 \mathrm{~m} \times 2.5 \mathrm{~m}$, respectively. Whereas, sole crop gave a net return of only $44198 /$-from wheat. The gain of '18098 and 4469/ha over sole crop was obtained with Eucalyptus and Melia based system, respectively.

Among spacing, the net gain of ' $17724,13733,12641$ and $6188 /$ ha over sole crop was realized with $3.0 \mathrm{~m} \mathrm{x}$ $1.0 \mathrm{~m}, 3.0 \mathrm{~m} \times 1.5 \mathrm{~m}, 3.0 \mathrm{~m} \times 2.0 \mathrm{~m}$ and $3.0 \mathrm{~m} \times 2.5 \mathrm{~m}$, respectively.

Apart from additional income over sole crop or traditional agri-system, fuel wood from pruning, soil fertility improvement and timber were major driving force for adoption for Eucalyptus and Melia wood. For spacings-the average of timber prices of all the species was taken to calculate income of agroforestry. Eucalyptus based commercial agroforestry systems are comparatively more profitable than Melia in agroforestry systems and the conventional cropping patterns. The contribution of the trees in the farming systems certainly added to the diversity dimension by way of income and employment to the farm households besides fulfilling the requirement of wood (Dwivedi et al., 2007). Correlation study: Correlations between growth, yield attributing characters and grain yield under two tree species were evaluated for the present study (Table 4). The grain yield shows high degree of positive correlation with all the yield attributes except spike length. However, germination count was perfectly $(\mathrm{r}=1)$ positive correlated with grain yield.

Germination count, dry matter accumulation and potential shoot had significant positive high degree of correlation ( $\mathrm{r}=0.75$ to 1 ) with all other growth parameters and yield except spike length. Spike length was significantly highly positive correlated only with grain per spike with significancy of $r=0.804$. Fertile spikelet/ spike, sterile spikelet/spike, grains/spike, 100 grain 
weight, grain, straw and biological yield showed significant high degree of positive correlation with each other. Similar data or result on these lines was also reported by Subhani and Chowdhry (2000) and Attarbashi et al. (2002). Sarvade et al., (2014) also found the similar results on correlation among the different wheat growth parameters.

The higher degree of correlation shows that the higher yield dependency of yield attributes on the crop growth and thus influences its yield. As the spike length did not show any significancy with other parameters and were positive and non-significantly correlated to each other $\left(\mathrm{r}<0.75^{\mathrm{NS}}\right)$, showing that as spike length increases the grains per spike will increase ultimately. The results from correlation of germination count indicated that significantly positive association with yield attributing characters like dry matter accumulation, potential shoot, spikelet per spike ${ }^{-1}$, grain per spike, grain yield etc. except spike length revealed that increase in germination count will cause corresponding increase in associated traits. Germination count $\left(\right.$ no. $\left./ \mathrm{m}^{2}\right)$ was perfectly positively associated and coefficient determination $(\mathrm{r}=1)$ with grain yield $(\mathrm{q} / \mathrm{ha})$, hence this yield component can be used as reliable selection criteria to improve grain yield in wheat.

\section{Conclusion}

From the present study, it may be concluded that $M e$ lia azedarach was found better for intercropping of wheat as it reduces competition for light with crop by shedding their leaves during crop sowing period which may helps to improve soil properties. Whereas, among the different tree spacing, wider spacing of $3 \mathrm{~m} \times 2.5 \mathrm{~m}$ was recorded superior in improving the growth, yield attributes and yields of wheat. However, economically wheat under Eucalyptus gain more income because of timber addition as of higher biomass accumulation in bole. Estimation of correlation among yield and yield components may provide effective selection criteria to improve wheat grain yield.

\section{REFERENCES}

Ahmed, R., Rafiqul Hoque, A.T.M., Hossain, M.K. (2008). Allelopathic effects of leaf litters of Eucalyptus camaldulensis on some forest and agricultural crops. J. Forestry Res. 19(1):19-24.

Attarbashi, M.R., Galeshi, S., Soltni, A. and Zinali, E. (2002). Relationship of phenology and physiological traits with grain yield in wheat under rain-fed conditions. Iranian Journal of Agricultural Science, 33:21-28

Bouycous, G.J. (1962). Direction for making mechanical analysis of soil by hydrometer method. Soil Science. 42 : 225-228.

Chauhan, V.K., Sood, S.K., Bhargawa, J.N. and Mishra, V.K. (1995). Effect of different trees on the yield of rainfed wheat crop. Annals of Forestry. 3 (2): 147-151.

Dwivedi,R.P.,Kareemulla,K.,Singh,R.,Rizvi,R.H. and Chauhan, J.(2007).Socio- EconomicAnalysisofAgroforestry-
SystemsinWesternUttarPradesh.Indian Research Journal of Extension Education.7(2\&3):18-22.

Fikreyesus, S., Kebebew, Z., Nebiyu, A., Zeleke, N, Bogale, S. (2011). Allelopathic effects of Eucalyptus camaldulensis Dehnh. on germination and growth of tomato. American-Eurasian J. Agric. Environ. Sci. 11(5):600608.

Fischer, R.A. (1985). Number of kernels in wheat crops and the influence of solar radiation and temperature. Journal of Agriculture Science(Camb.). 105: 447-461.

Fischer, R.and Stockman, Y.M. (1980). Kernel number per spike in wheat (Triticum aestivum L.): responses to preanthesis shading. AustralianJournal of Plant Physiology. 7: 169-180.

Garrity, D.P. (2004). Agroforestry and the achievement of the millennium development goals. Agroforestry Systems. 61:5-17.

Gibson, N. (1978). The economics of wood biomass. In: Energy from biomass and wastes. Symposium of the Institute of Gas Technology, Washington, D.C. 39-49.

Jackson, M.L. (1973). Soil chemical analysis. Prentice Hall of India Pvt. Ltd. New Delhi, India. pp.186-192,195-196

Jiang, J.P., Zhu, J.J., Liu, T.Z., He, S.M., Zhou, Z.M. and Su, F.J. (1994). Related changes of wheat yield and photosynthtically active radiation in Paulownia-wheat intercropping system. Acta Agriculture Boreali Sinica. 9:133 -137 (c.f. Agroforestry Abstracts, 1995. 8, 3, 114).

Kaushik, N. and Singh, J. (2001). Performance of pearl millet - wheat in Poplar based agri- silvicultural system in sandy soils of southern Haryana. Indian Journal Agroforestry. 3 (1): 51-54.

Khan, G.S. and Ehrenreich, J.H. (1994). Effect of increasing distance from Acacia nilotica trees on wheat yield. Agroforestry Systems. 25 (1): 23-29.

Kidanu, S., Mamo, T. and Stroosnijder, L. (2005). Biomass production of Eucalyptus boundary plantations and their effect on crop productivity on Ethiopian highland Vertisols. Agroforestry Systems. 63 (3): 281-290.

Kumar, B.M. (2006). Agroforestry: the new old paradigm for Asian food security. Journal of Tropical Agriculture. 44 (1-2):1- 14.

Kumar, V, Rajput, P.R. (2003). Studies on yield and yield components of wheat varieties in open and under poplar (Populus deltoides Bartr. Ex. Marsh) based agrosilviculture system. Plant Archives. 3(2):183-189.

Lakshmamma, P. and Subba Rao, I.V. (1996). Influence of shading and Naphthalene Acetic Acid (NAA) on yield and yield component in black gram (Vigna mungo. L). Annalsof Agriculture Research. 17 (3): 320-321.

$\mathrm{Mu}$, H., Jiang, D., Wollenweber, B., Dai, T., Jing, Q. and Cao, W. (2010). Long-term low radiation decreases leaf photosynthesis, photochemical efficiency and grain yield in winter wheat. Crop ScienceJournal. 196:38-47

Nandal, D.P.S. and Singh, R.R. (2001). Productivity of different cropping sequences in Dalbergia sissoo Roxb. based agro-silviculture system. Indian Journal of Forestry. 24 (4): 433-436.

Nazir, M.S., Ahmad, R., Eshanullah and Cheema, S.A. (1993). Quantitative analysis of effect of Shisham tree shade in wheat. Pakistan J. Agric. Res. 14 (1): 12-17.

Pande, P.K. (2011). Variation in Wood Properties and Growth in Some Clones of Populus deltoides Bartr. ex Marsh. American Journal of Plant Sciences. 2: 644-649. 
Panse, V.G. and Sukhatme, P.V. (1967). Statistical Methods for Agriculture Workers. $4^{\text {th }}$ ed., New Delhi, ICAR. pp.359.

Patil, R.H., Hunshal, C.S. and Itnal, C.J. (2002). Influence of bund planted Eucalyptus tree row on winter wheat. Allelopathy Journal. 10 (1): 21-28.

Puri, S. and Nair, P.K.R. (2004). Agroforestry research for development in India: 25 years of experience of a national program. Agroforestry Systems. 61/62: 437-452.

Puri, S., Sao, B. and Swamy, S.L. (2001). Growth and productivity of wheat varieties in an agrisilviculture system. Indian Journal of Agroforestry. 3 (2): 134-138.

Sarvade, S., Mishra, H.S., Rajesh Kaushal, Sumit Chaturvedi, Salil Tewari and Jadhav, T.A., (2014). Performance of wheat (Triticum aestivum L.) crop under different spacings of trees and fertility levels. African Journal of Agricultural Research. 9 (9): 866-873.

Sidhu, D.S. and Hans, A.S. 1988. Preliminary studies on the effect of Eucalyptus leaf litter on accumulation of biomass in wheat. Journal of Tropical Forestry, 4(4):328-333

Snedecor, G.W., Cochran, G.W.(1967). Statistical methods. 6th ed. Calcutta. IBH Publishing Company, 310.
Stockman, Y.M., Fischer, R.A. and Brittain, E.G. (1983). Assimilate supply and floret development within the spike of wheat. Australian Journal of Plant Physiology. 10: 585-594.

Subbiah, B.V. and Asija, G.I. (1956). A rapid procedure for the determination of available nitrogen in soils. Current Science. 25: 259-260.

Subhani, G.M. and Chowdhry, M.A. (2000). Correlation and path coefficient analysis in bread wheat under drought stress and normal conditions. Pakistan Journal of Biological Science. 3:72-77.

Tripathi, M.K., Saini, B.C. and Chaturvedi, S. (2006) Growth and yield of intercropped wheat under Salix and Dalbergia agroforestry system. Annals of Biology, 22 (2): 189-191.

Verma, K.S., Zegeye, M.W. and Kaushal, R. (2002). Growth and yield performance of wheat in agri-hortisilvicultural system of agroforestry in the mid-hills of Himachal Himalayas. Indian Journal of Agroforestry, 4 (1): 1-7.

Walkley, A.J. and Black, I.A. (1934). Estimation of soil organic carbon by chronic acid titration method. Soil Science. 37: 29-38. 